\title{
A Highly Efficient Coordination Polymer for Selective Trapping and Sensing Perrhenate/Pertechnetate
}

\author{
Cheng-Peng Li, ${ }^{\dagger}{ }^{\dagger+}$ Hang Zhou, ${ }^{\dagger}$ Jing Chen,${ }^{\dagger}$ Jia-Jun Wang, ${ }^{\dagger}$ Miao Du ${ }^{*, \dagger}$ and Wuzong Zhou ${ }^{*,}$ \\ $\dagger$ Tianjin Key Laboratory of Structure and Performance for Functional Molecules, MOE Key \\ Laboratory of Inorganic-Organic Hybrid Functional Material Chemistry, College of Chemistry, Tianjin \\ Normal University, Tianjin 300387, P. R. China \\ $¥$ School of Chemistry, University of St Andrews, St Andrews, Fife KY169ST, UK
}

Keywords: Coordination Polymers; Perrhenate/Pertechnetate; Anion Exchange; Fluorescence Sensor; Test Paper 


\section{ABSTRACT}

A porous cationic $\mathrm{Ag}(\mathrm{I})$ coordination polymer, $[\mathrm{Ag}(1,2,4,5-\mathrm{p} 4 \mathrm{~b})]\left(\mathrm{SbF}_{6}\right)(\mathrm{TJNU}-302)$ with the ligand 1,2,4,5-p4b (1,2,4,5-tetra(pyridin-4-yl)benzene), is reported, which shows high sorption capacity $\left(211 \mathrm{mg} \mathrm{g}^{-1}\right)$ and distribution coefficient $K_{\mathrm{d}}\left(5.8 \times 10^{5} \mathrm{~mL} \mathrm{~g}^{-1}\right)$ as well as outstanding selectivity in 500 times excess of $\mathrm{CO}_{3}{ }^{2-}$ or $\mathrm{PO}_{4}{ }^{3-}$ anion for perrhenate removal. TJNU-302 can act as a crystalline turn-off sensor for perrhenate upon UV radiation. In this way, a test paper strip for sensing $\mathrm{ReO}_{4}^{-}$could be produced. In water solution, TJNU-302 shows efficient fluorescence quenching response to $\mathrm{ReO}_{4}^{-}$ion, with the highest quenching percentage (86\%) among all reported $\mathrm{ReO}_{4}^{-}$sensors. These results could be elucidated by the bonding properties of single-crystal structures of TJNU-302 before and after perrhenate sorption, as well as density functional theory (DFT) calculations. 


\section{INTRODUCTION}

Recognition and removal of toxic and radioactive waste from water is of immense interest to national security, countering terrorism, and environmental protection. ${ }^{1,2}$ Technetium is an important by-product of the nuclear industry, especially in nuclear reactors during the nuclear fission of uranium. ${ }^{3,499} \mathrm{Tc}$ shows a long half-life $\left(t_{1 / 2}=2.13 \times 10^{5}\right.$ years $)$ and exists primarily in its most stable oxidation state (VII), as pertechnetate $\left({ }^{99} \mathrm{TcO}_{4}^{-}\right)$. It is a huge challenge to remediate ${ }^{99} \mathrm{TcO}_{4}^{-}$contaminated environment, for its high solubility in water and high environmental mobility. ${ }^{5}$ Furthermore, direct study of $\mathrm{TcO}_{4}^{-}$is extremely limited, considering its radioactivity and government restriction. As a result, its non-radioactive surrogate perrhenate $\left(\mathrm{ReO}_{4}^{-}\right)$is usually used instead, which has similar charge density and thermodynamic parameters to $\mathrm{TcO}_{4}^{-}$.

Due to the large size and low charge density, selective recognition and removal of $\mathrm{TcO}_{4}{ }^{-}$ $/ \mathrm{ReO}_{4}{ }^{-}$ions pose huge difficulty, especially after an accidental release of these anions into ground water. To date, several materials have been applied to immobilize or remove $\mathrm{TcO}_{4}{ }^{-}$ ion from water, including anion-exchange resins, ${ }^{6,7}$ supramolecular receptors,,${ }^{8,9}$ crystalline inorganic cationic materials, ${ }^{10}$ organic polymeric networks, ${ }^{11-16}$ and coordination polymers (CPs). ${ }^{17-20}$ Very recently, CPs showing the structural designability and diversity as well as outstanding functionalization, have been considered as promising candidates for selective anion receptors. $^{21-26}$

As for selective recognition or detection, the current common instrumental methods, such as ion chromatography, inductively coupled plasma mass spectrometry (ICP-MS), and high-performance liquid chromatography coupled with atomic absorption spectrometry, 
are expensive and time-consuming. In comparison, chemical luminescent sensors are more economical and convenient for detection. As a general strategy to $\mathrm{TcO}_{4}^{-} / \mathrm{ReO}_{4}{ }^{-}$detection, a designed sensor with particular fluorophore interacting with the sorbed anions, will show significant changes of fluorescence. ${ }^{27-29}$ In this way, the recognition and quantification of $\mathrm{TcO}_{4}^{-} / \mathrm{ReO}_{4}^{-}$can be achieved. Amendola et al have reported the first molecular receptor for ${ }^{99} \mathrm{TcO}_{4}^{-}$, which shows good turn off effect of the receptor's emission. ${ }^{30}$ However, the capture ability was not mentioned and only the selectivity to monovalent anions (e.g. $\mathrm{ClO}_{4}^{-}$ , $\mathrm{NO}_{3}{ }^{-}$, and $\mathrm{HSO}_{4}{ }^{-}$) was demonstrated. Desai and Singh have reported a fluorescence turn on $\mathrm{ReO}_{4}^{-}$sensor, Thioflavin- $\mathrm{T}$, which shows ordinary selectivity (10-fold to competing anions) and detection limit $(260 \mu \mathrm{M}) \cdot{ }^{31}$ To our best knowledge, there is only one report on CP luminescent sensor for $\mathrm{TcO}_{4}{ }^{-} / \mathrm{ReO}_{4}{ }^{-} \cdot 32$ Thereinto, MOR-1 and MOR-2 exhibit $62 \%$ and $63 \%$ emission quenching as determined by fluorescence titration. The whole process could be traced by fluorescence spectrometer. However, it cannot fulfill the requirements of field operation. In practice, the test paper strip is one of the fastest and easiest tools to detect the target species. Thus, a real-time test paper strip for sensing $\mathrm{TcO}_{4}{ }^{-} / \mathrm{ReO}_{4}{ }^{-}$is of great interest and necessity.

With this in mind, we have designed and prepared a unique CP-based test paper for $\mathrm{ReO}_{4}{ }^{-}$ capture and detection. This CP is designated as TJNU-302 (TJNU denotes Tianjin Normal University), showing a 2-fold interpenetrated 3D cationic framework with the inclusion of lattice $\mathrm{SbF}_{6}{ }^{-}$anions. This material possesses fast exchange kinetics, high sorption capacity and distribution coefficient $\left(K_{\mathrm{d}}\right)$, and outstanding selectivity to $\mathrm{ReO}_{4}^{-}$over other competing anions (500 times excess of $\mathrm{CO}_{3}{ }^{2-}$ or $\mathrm{PO}_{4}{ }^{3-}$ ). As far as we know, TJNU-302 has the highest 
quenching efficiency $(86 \%)$ among all reported perrhenate sensors. ${ }^{32}$ Owing to the fact that the TJNU-302 crystals can show an obvious quenching effect to perrhenate solution, a realtime test paper for $\mathrm{ReO}_{4}^{-}$was fabricated. Moreover, the mechanism of $\mathrm{ReO}_{4}^{-}$trapping by TJNU-302 has been revealed via single crystal to single crystal (SC-SC) transformation and further, supported by density functional theory (DFT) calculations.

\section{EXPERIMENTAL SECTION}

Materials and Methods. All chemicals were used as received without further purification. Here, the deionised water was used throughout. 1,2,4,5-Tetra(pyridin-4-yl)benzene (98\%) was purchased from Tianjin Dadikanghe Co., Ltd. $\mathrm{KReO}_{4}(99 \%)$ and $\mathrm{AgSbF}_{6}(>98 \%)$ were purchased from Tianjin Chemical Technology Co., Ltd. The nylon membrane filter $(0.22$ $\mu \mathrm{m})$ was purchased from Tianjin Navigator Lab Instrument Co., Ltd, which shows a small $\mathrm{ReO}_{4}^{-}$sorption capacity of only $3.90 \%$ toward the $\mathrm{KReO}_{4}$ water solution (500 ppm), as determined by ICP-OES. Elemental analysis was performed on a Vario EL III elemental analyzer. FT-IR spectra (KBr pellet) were taken on a Bruker Alfa FT-IR spectrometer. Powder X-ray diffraction (PXRD) patterns were recorded on a Rigaku model Ultima IV diffractometer with Rigaku D/teX ultrahigh-speed position sensitive detector and $\mathrm{Cu}-\mathrm{K} \alpha$ X-ray (40 kV and $100 \mathrm{~mA})$, by using a step-scan mode with a scan rate of $2 \%$ min and step size of $0.02^{\circ}$. Simulation of PXRD patterns was taken using the diffraction-crystal module of Mercury based on single-crystal diffraction data. Scanning electron microscopy (SEM) and energy-dispersive X-ray spectroscopy (EDS) were conducted on a FEI Nova Nano 230 scanning electron microscope with the electron beam energy of 15 or $20 \mathrm{keV}$. Inductively 
coupled plasma mass spectroscopy (ICP-MS) analysis was performed with a Perkin-Elmer ELAN 9000 instrument after digestion of the sample in $\mathrm{HNO}_{3}$. Inductively coupled plasma optical emission spectrometer (ICP-OES) analysis was taken using a Perkin-Elmer Avio 200 instrument after digestion of the sample in $\mathrm{HNO}_{3}$. Fluorescence spectra were recorded on a FL-1065 spectrometer.

Single-Crystal X-Ray Diffraction. Single crystal X-ray diffraction (SC-XRD) data were collected on an Agilent SuperNova Dual diffractometer with an AtlasS2 detector and $\mathrm{Cu}$ K $\alpha$ radiation $(\lambda=1.54184 \AA)$ at $293 \mathrm{~K}$ for both TJNU-302 and TJNU-302(Re). Multi-scan absorption corrections were performed using the SADABS program. The structures were solved by direct methods, and all non-hydrogen atoms were refined anisotropically by fullmatrix least-squares method with SHELXTL software package. The final refinements were conducted by full-matrix least-squares methods with anisotropic thermal parameters for all non-H atoms on $F^{2}$. Generally, C-bound $\mathrm{H}$ atoms were geometrically located and refined using the riding model. Isotropic displacement parameters of $\mathrm{H}$ atoms were derived from their parent atoms. Further crystal data and structural refinement details are listed in Table S1 and selected bond lengths and angles are shown in Table S2 (Supporting Information). Synthesis of $\left[\mathbf{A g}(\mathbf{1 , 2 , 4 , 5 - p 4 b )}]\left(\mathbf{S b F}_{\mathbf{6}}\right)\right.$ (TJNU-302). $\mathrm{A} \mathrm{CH}_{3} \mathrm{OH}$ solution $(3 \mathrm{~mL})$ of 1,2,4,5p4b (19.3 mg, $0.05 \mathrm{mmol})$ was carefully layered on an aqueous solution ( $3 \mathrm{~mL}) \mathrm{of} \mathrm{AgSbF}_{6}$ (17.1 mg, $0.05 \mathrm{mmol})$, with ethyl acetate as the intermediate layer in a straight glass tube. Colorless block crystals were obtained by slow evaporation of solvent at room temperature after three days. Yield: ca. $32 \mathrm{mg}$. Anal. calcd for $\mathrm{C}_{26} \mathrm{H}_{18} \mathrm{~N}_{4} \mathrm{~F}_{6} \mathrm{SbAg}$ : C, 42.77; H, 2.49; N, 
7.67\%. Found: C, 42.57; H, 2.44; N, 7.72\%. FT-IR $\left(\mathrm{cm}^{-1}\right): 1603 v s, 1547 m, 1475 w, 1420 s$, $1219 m, 1068 m, 1011 m, 825 s, 747 w, 630 v s, 562 m, 541 m$.

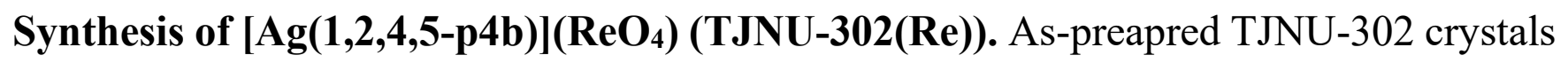
$(15 \mathrm{mg})$ were immersed in an aqueous solution of $\mathrm{KReO}_{4}(5 \mathrm{~mL}, 0.05 \mathrm{mmol})$ for one day. Good quality crystals were isolated. Anal. calcd for $\mathrm{C}_{26} \mathrm{H}_{18} \mathrm{AgN}_{4} \mathrm{O}_{4} \mathrm{Re}$ : C, 41.94; H, 2.44; N, 7.53\%. Found: C, 41.95; H, 2.43; N, 7.52\%. FT-IR ( $\left.\mathrm{cm}^{-1}\right): 1593 v s, 1543 m, 1473 w$, $1407 s, 1213 w, 1090 w, 1051 s, 993 v s, 912 v s, 818 s, 557 m$.

Typical Perrhenate Adsorption Method. As-synthesized TJNU-302 crystals (37 mg, ca. $0.05 \mathrm{mmol})$ were added to a water solution $(20 \mathrm{~mL})$ of $\mathrm{KReO}_{4}(58 \mathrm{mg}, 0.2 \mathrm{mmol})$ and the mixture was stirred at room temperature. The solids were monitored using FT-IR, PXRD, SEM-EDS elemental mapping and ICP-OES at various time intervals.

Adsorption Data Fitting by Kinetics Model. As-synthesized TJNU-302 crystals (110 mg, ca. $0.15 \mathrm{mmol})$ were immersed into an aqueous solution $(30 \mathrm{~mL})$ of $\mathrm{KReO}_{4}(0.03 \mathrm{mmol})$ and stirred at room temperature. Then, the solution was separated at different time intervals by a nylon membrane filter $(0.22 \mu \mathrm{m})$. The concentration of $\mathrm{ReO}_{4}{ }^{-}$remaining in the water phase and the corresponding $\mathrm{ReO}_{4}^{-}$removal percentage by TJNU-302 were determined by ICP-OES measurement. The equation of linearized form of pseudo-second-order model is shown in equation (1), where the measured $q_{t}$ and $q_{e}\left(\mathrm{mg} \mathrm{g}^{-1}\right)$ are the $\mathrm{ReO}_{4}{ }^{-}$uptake amount at $t$ min and at equilibrium, respectively, and $k_{2}\left(\mathrm{~g} \mathrm{mg}^{-1} \mathrm{~min}^{-1}\right)$ is the pseudo-second-order rate constant.

$$
\frac{t}{q_{t}}=\frac{t}{q_{e}}+\frac{1}{k_{2} q_{e}^{2}}
$$


Adsorption Data Fitting by Isotherm Models. As-synthesized TJNU-302 crystals (5 mg) were immersed into an aqueous solution $(10 \mathrm{~mL})$ of $\mathrm{KReO}_{4}$ with the concentration of 500 , $450,400,300,250,150,100,25$, or $20 \mathrm{ppm}$. The mixture was stirred at room temperature for $24 \mathrm{~h}$ to make sure that an equilibrium was achieved, after which the concentration of residual $\mathrm{ReO}_{4}^{-}$ion in water phase was unchanged as determined by ICP-MS. The solution was separated from the crystals with a nylon membrane filter $(0.22 \mu \mathrm{m})$. The concentration of residual $\mathrm{ReO}_{4}^{-}$in water phase and the trapping percentage of $\mathrm{ReO}_{4}^{-}$were measured by ICP-MS. In order to determine the adsorption thermodynamics of $\mathrm{ReO}_{4}^{-}$by TJNU-302, Langmuir and Freundlich sorption models were used.

In the Langmuir model, the adsorption was assumed to occur on a homogeneous solid surface of TJNU-302, following a monolayer sorption process. The equation of Langmuir model is

$$
\frac{c_{e}}{q_{e}}=\frac{1}{q_{m} k_{L}}+\frac{c_{e}}{q_{m}}
$$

where $c_{e}$ is the equilibrium concentration of anions $\left(\mathrm{mg} \mathrm{L}^{-1}\right), q_{e}$ and $q_{m}$ are the equilibrium and maximum sorption amounts $\left(\mathrm{mg} \mathrm{g}^{-1}\right)$, and $k_{L}$ is a constant indirectly related to sorption amount and energy of sorption $\left(\mathrm{L} \mathrm{mg}^{-1}\right)$. The fitting line was carried out by plotting $c_{e} / q_{e}$ against $c_{e}$. The values of $q_{m}$ and $k_{L}$ can be calculated from the slope and intercept.

The Freundlich adsorption model is based on a heterogeneous surface, which suggests different binding energies between the anions and surface sites of TJNU-302. The equation of the Freundlich model is

$$
\ln q_{e}=\ln k_{F}+\frac{1}{n} \ln c_{e}
$$


where $c_{e}$ and $q_{e}$ are the equilibrium concentration of anions $\left(\mathrm{mg} \mathrm{L}^{-1}\right)$ and the equilibrium sorption amount $\left(\mathrm{mg} \mathrm{g}^{-1}\right)$, and $k_{F}$ and $n$ are the Freundlich constants, which are related to sorption amount $\left(\mathrm{mg} \mathrm{g}^{-1}\right)$ and adsorption intensity, characterizing the affinity of adsorbate with the adsorbent.

Hydrolytic Stability. As-synthesized TJNU-302 crystals (20 mg) were immersed in $\mathrm{HNO}_{3}$ or $\mathrm{NaOH}$ solution of different $\mathrm{pH}$ values and stirred at room temperature for $24 \mathrm{~h}$. Then, the solid was collected by filtration and washed with water several times. The solids were

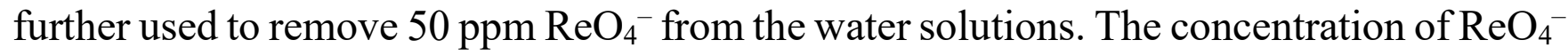
ion remaining in the water phase and the corresponding trapping percentage of $\mathrm{ReO}_{4}^{-}$were determined by ICP-MS. The solids were washed with water, dried, and characterized using PXRD.

Anion Selectivity. The competing effect with other anions, including $\mathrm{SO}_{4}{ }^{2-}, \mathrm{CO}_{3}{ }^{2-}, \mathrm{NO}_{3}{ }^{-}$, $\mathrm{PO}_{4}{ }^{3-}, \mathrm{CF}_{3} \mathrm{COO}^{-}, \mathrm{CH}_{3} \mathrm{SO}_{3}{ }^{-}$, and $\mathrm{F}^{-}$, was performed by adding TJNU-302 (10 mg) into an aqueous solution of $\mathrm{ReO}_{4}^{-}\left(10 \mathrm{~mL}, 0.025 \mathrm{mmol} \mathrm{L}^{-1}\right)$ containing another type of anion (in mmol L ${ }^{-1}$ ), e.g. $25 \mathrm{Na}_{2} \mathrm{SO}_{4}, 2.5 \mathrm{Na}_{2} \mathrm{CO}_{3}, 1.25 \mathrm{NaNO}_{3}, 1.25 \mathrm{~K}_{3} \mathrm{PO}_{4}, 0.5 \mathrm{CF}_{3} \mathrm{COONa}, 0.5$ $\mathrm{CH}_{3} \mathrm{SO}_{3} \mathrm{Na}$, or $0.25 \mathrm{NaF}$. Then, the sample was washed with water, dried and characterized using FT-IR. Further, the effect of $\mathrm{CO}_{3}{ }^{2-}$ (or $\mathrm{PO}_{4}{ }^{3-}$ ) was tested by adding $10 \mathrm{mg}$ of TJNU302 to the $\mathrm{ReO}_{4}^{-}$solution $\left(10 \mathrm{~mL}, 0.025 \mathrm{mmol} \mathrm{L}^{-1}\right)$ containing $2.5,5.0,7.5,10.0$ and 12.5 mmol L-1 $\mathrm{Na}_{2} \mathrm{CO}_{3}$ (or $\mathrm{K}_{3} \mathrm{PO}_{4}$ ), respectively. The concentration of $\mathrm{ReO}_{4}^{-}$ion in water after adsorption was determined by ICP-MS.

\section{Recyclability}


In the first cycle, TJNU-302 (50 mg) was immersed in a $\mathrm{KReO}_{4}$ solution $(20 \mathrm{~mL}, 180 \mathrm{ppm})$ for $24 \mathrm{~h}$. After that, the $\mathrm{ReO}_{4}^{-}$sorbed material was stirred in $\mathrm{NaSbF}_{6}$ solution $\left(1 \mathrm{~mol} \mathrm{~L}^{-1}\right.$, $50 \mathrm{~mL}$ ) under heating at $50{ }^{\circ} \mathrm{C}$. The solid was collected by centrifugation. Such recovered material was then subject to the next recyclability. Stability of regenerated TJNU-302 was verified by PXRD and the $\mathrm{ReO}_{4}{ }^{-}$removal ratio in each run was determined by ICP-OES.

Preparation of TJNU-302 Suspension for Luminescent Sensing. A water suspension of TJNU-302 was prepared by dispersing $1 \mathrm{mg}$ TJNU-302 crystals into $3 \mathrm{~mL}$ water, followed by the ultrasonic treatment for $20 \mathrm{~min}$, and then used in the following tests.

Fluorescence Response to $\mathbf{R e O}_{4}^{-}$. Titration experiment for sensing $\mathrm{KReO}_{4}$ was performed by a continuous addition of $\mathrm{KReO}_{4}$ solution $\left(0.02 \mathrm{~mol} \mathrm{~L}^{-1}\right)$ into the TJNU-302 suspension. The quenching percentage $(\mathrm{QP})$ was calculated with $\left(1-I / I_{o}\right) \times 100 \%$ and the quenching effect of $\mathrm{KReO}_{4}$ was quantified by Stern-Volmer constant $\left(K_{\mathrm{sv}}\right)$, which was calculated from the Stern-Volmer equation $I_{0} / I=K_{\mathrm{sv}}[\mathrm{M}]+1$. Herein, $I_{0}$ and $I$ are the luminescence intensity without and with adding $\mathrm{KReO}_{4}$ solution, respectively, and $[\mathrm{M}]$ is the molar concentration of quencher $\mathrm{ReO}_{4}^{-}$.

Effect of pH on Fluorescence Response to $\mathbf{R e O}_{4}^{-}$. The TJNU-302 suspensions ( $3 \mathrm{~mL}$ ) at different $\mathrm{pH}$ values (e.g. 3, 5, 7, 10, and 13) were prepared by mixing with $\mathrm{HNO}_{3}$ or $\mathrm{NaOH}$ solution. After that, $\mathrm{KReO}_{4}$ solution $\left(200 \mu \mathrm{L}, 0.02 \mathrm{~mol} \mathrm{~L}^{-1}\right)$ was added to each suspension. The luminescence intensity of each sample was collected.

Fluorescence Response to Other Anions. An aqueous solution of $\mathrm{SO}_{4}{ }^{2-}(100 \mu \mathrm{L}, 0.2 \mathrm{~mol}$ $\mathrm{L}^{-1}$ ) was added into TJNU-302 suspension. After ca. 5 min, the luminescence of suspension 
was measured and the quenching percentage was calculated by equation $\left(1-I / I_{o}\right) \times 100 \%$.

The fluorescence responses to $\mathrm{CO}_{3}{ }^{2-}, \mathrm{Cl}^{-}, \mathrm{NO}_{2}{ }^{-}$, and $\mathrm{NO}_{3}{ }^{-}$were similarly studied.

Fluorescence Response to Low Activity Waste (LAW). A simulated Hanford LAW Melter Recycle Stream was prepared, in which $\mathrm{TcO}_{4}^{-}$was replaced with $\mathrm{ReO}_{4}{ }^{-}$(Table S3, Supporting Information). ${ }^{11}$ In addition, a simulated LAW solution without $\mathrm{ReO}_{4}{ }^{-}$ion was prepared for comparison. Then, a $100 \mu \mathrm{L}$ simulated LAW solution with or without $\mathrm{ReO}_{4}^{-}$ anion was added into the TJNU-302 suspension. After $5 \mathrm{~min}$, the fluorescence intensity of suspension was tested and the quenching percentage was calculated by $\left(1-I / I_{o}\right) \times 100 \%$.

Computational Methods. All calculations were carried out with density functional theory (DFT) within the projected-augmented plane wave method ${ }^{33,34}$ as implemented in Vienna ab initio simulation package (VASP). ${ }^{35}$ The generalized gradient approximation suggested by Perdew, Burke, and Ernzerhof with London dispersion corrections proposed by Grimme (PBE-D2) was employed to accurately describe the weak interactions. ${ }^{36,37}$ The MonkhorstPack mesh was employed to sample the Brillouin zone for geometry optimizations and electronic structure calculations. ${ }^{38}$ In current calculations, a plane-wave cutoff energy of $500 \mathrm{eV}$ was used and all atomic positions were relaxed at the PBE level until the atomic force was less than $0.01 \mathrm{eV} \AA^{-1}$. The tolerance for energy convergence was set to $10^{-5} \mathrm{eV}$.

\section{RESULTS AND DISCUSSION}

Crystal Structure of TJNU-302. The targeted TJNU-302 material was designed based on $\operatorname{Ag}(\mathrm{I})$ cation and 1,2,4,5-p4b ligand, which bears four binding sites and may adopt diverse 
conformations caused by the rotation of pyridyl groups. Such a flexible and neutral ligand will facilitate the construction of cationic coordination network with $\operatorname{Ag}(\mathrm{I})$ ions.

Structural analysis of TJNU-302 crystal reveals that it is monoclinic with $a=14.1795(3)$, $b=8.7989(2), c=20.5217(4) \AA, \beta=102.312(2)^{\circ}$, and space group $P 2_{1} / n$ (Table S1, Supporting Information). The asymmetric unit is composed by one $\mathrm{Ag}(\mathrm{I})$ center, two half 1,2,4,5-p4b ligands, and one $\mathrm{SbF}_{6}{ }^{-}$anion (Figure 1a). Each $\mathrm{Ag}(\mathrm{I})$ center is ligated by three 1,2,4,5-p $4 \mathrm{~b}$ ligands to constitute a trigonal geometry. For the two 1,2,4,5-p4b ligands, their coordination modes are different, where one $(\mathrm{N} 1, \mathrm{~N} 3)$ is a square-planar linker and the other $(\mathrm{N} 2, \mathrm{~N} 4)$ is a linear linker. As a consequence, the $\mathrm{Ag}(\mathrm{I})$ ions are linked by the 1,2,4,5-p4b ligands to form a 3D coordination network. Moreover, two such networks are intertangled to afford a 2-fold interpenetrating architecture, with the inclusion of $\mathrm{SbF}_{6}{ }^{-}$anions (Figure 1b). By considering each $\mathrm{Ag}(\mathrm{I})$ ion and each $(\mathrm{N} 1, \mathrm{~N} 3)-1,2,4,5-\mathrm{p} 4 \mathrm{~b}$ ligand as the nodes, this 3 D network can be simplified into a $(3,4)$-connected $\left(8^{3}\right)_{2}\left(8^{5} 10\right)$ topology prototype (Figure S1, Supporting Information). 

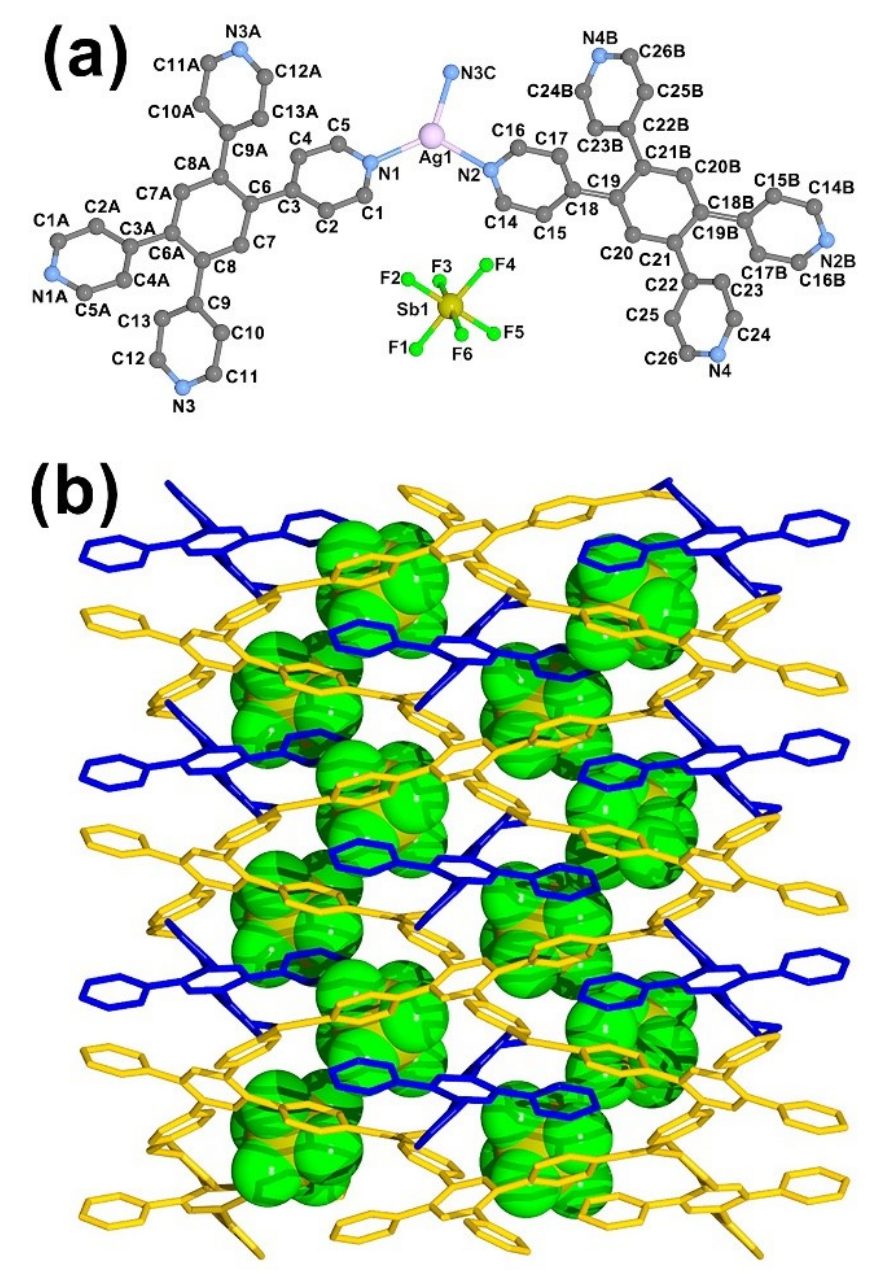

Figure 1. Crystal structure of TJNU-302. (a) Coordination environment of $\mathrm{Ag}(\mathrm{I})$ and location of $\mathrm{SbF}_{6}{ }^{-}$anion. (b) Two-fold interpenetrated architecture of TJNU-302, showing the included $\mathrm{SbF}_{6}{ }^{-}$anions in space-filling model.

$\mathrm{ReO}_{4}{ }^{-}$Sorption. Anion exchange of $\mathrm{ReO}_{4}^{-}$was explored by immersing TJNU-302 crystals (37 mg, ca. $0.05 \mathrm{mmol})$ into an aqueous solution $(20 \mathrm{~mL})$ of $\mathrm{KReO}_{4}(58 \mathrm{mg}$, ca. $0.2 \mathrm{mmol})$. The process was monitored by FT-IR, PXRD, SEM-EDS elemental mapping and ICP-OES. As shown in Figure 2a, a new strong IR peak appears at ca. $902 \mathrm{~cm}^{-1}$ within 1 min of anion exchange, revealing the formation of $\mathrm{ReO}_{4}^{-}$-loaded TJNU-302. When the anion-exchange proceeds for $10 \mathrm{~min}$, the intensity of IR peak at $902 \mathrm{~cm}^{-1}$ further increases, but the peak at $631 \mathrm{~cm}^{-1}$ of $\mathrm{SbF}_{6}{ }^{-}$disappears, indicating the completion of anion exchange. 

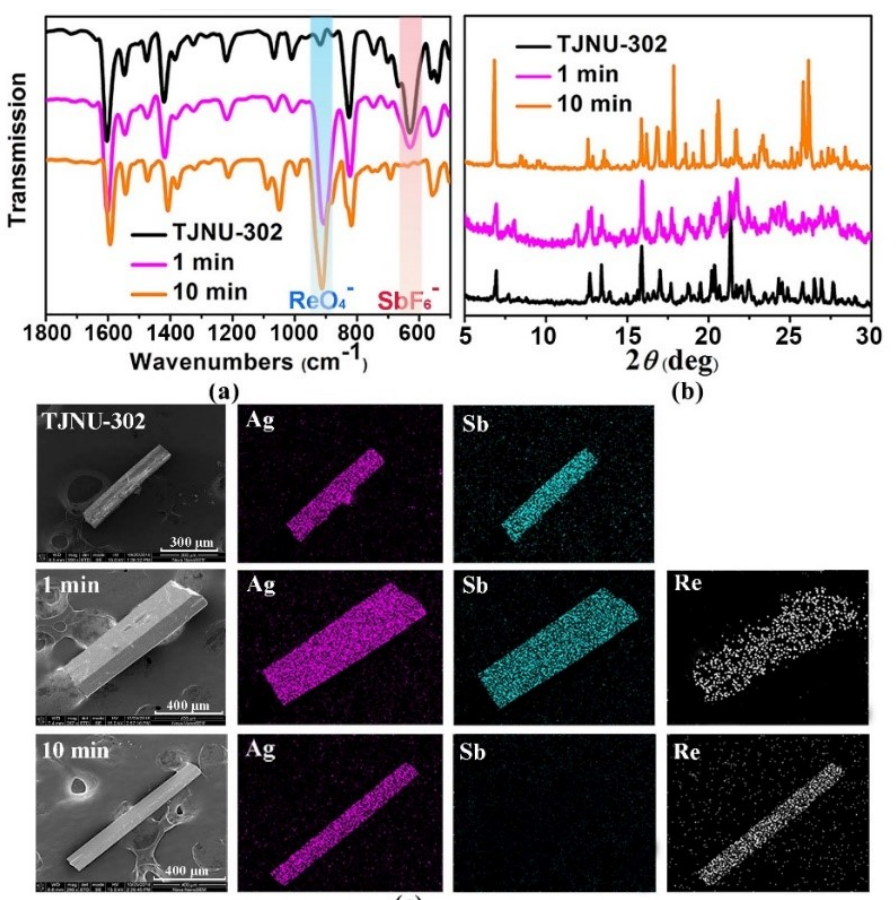

Figure 2. (a) FT-IR spectra and (b) PXRD patterns of TJNU-302 at different anionexchange levels. (c) The corresponding SEM images and EDS elemental mappings of $\mathrm{Ag}, \mathrm{Sb}$ and $\mathrm{Re}$ for the crystals.

The PXRD patterns of both the initial and final samples show good crystallinity, whereas the sample after 1 min of anion-exchange shows a relatively low crystallinity (Figure $2 b$ ). Nevertheless, the crystal morphology is well retained after the reaction. Figure $2 \mathrm{c}$ shows the SEM images of typical crystals from the samples, together with their elemental maps of $\mathrm{Ag}, \mathrm{Sb}$, and Re. Clearly, $\mathrm{Ag}$ is from the TJNU-302 framework and its distribution does not change during the anion-exchange. Other than Ag, the original TJNU-302 crystal only contains $\mathrm{Sb}$, while the crystal after anion-change for 10 min shows only Re. As anticipated, the crystal after 1 min of anion-exchange contains evenly distributed $\mathrm{Sb}$ and $\mathrm{Re}$. The final product was also characterized by ICP-OES, which reveals that all $\mathrm{SbF}_{6}{ }^{-}$in TJNU-302 can be quantitatively exchanged by $\mathrm{ReO}_{4}^{-}$. 
To further evaluate the ability of TJNU-302 as scavenger for $\mathrm{ReO}_{4}{ }^{-}$removal, the sorption kinetics was studied by soaking TJNU-302 crystals ( $110 \mathrm{mg}$, ca. $0.15 \mathrm{mmol})$ into a $\mathrm{KReO}_{4}$ solution $(0.03 \mathrm{mmol}, 30 \mathrm{~mL})$. As determined by ICP-OES analysis of the solution, $97.1 \%$ and $99.9 \%$ of $\mathrm{ReO}_{4}{ }^{-}$anions were rapidly removed after 5 and 10 min, respectively (Figure 3a). The kinetics for $\mathrm{ReO}_{4}^{-}$sorption from water can be described by Equation (1) given in the Experimental Section. As a result, it shows a pseudo-second-order reaction with a very good correlation coefficient (0.999), and the pseudo-second-order rate constant $k_{2}(0.1022$ $\mathrm{g} \mathrm{mg}^{-1} \mathrm{~min}^{-1}$ ) can be obtained from the fitted plots via $t / q_{t}$ vs. $t$.
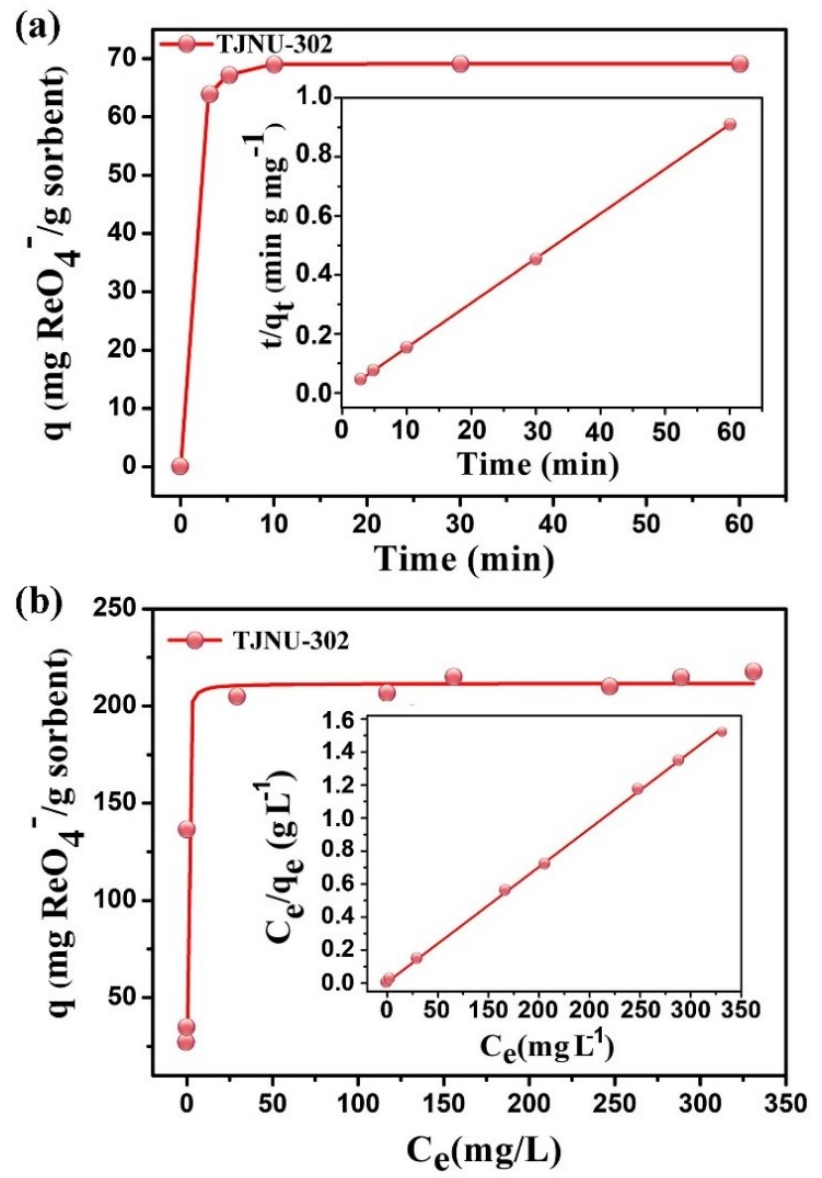

Figure 3. (a) $\mathrm{ReO}_{4}{ }^{-}$sorption curve vs. time in TJNU-302 suspension. Inset: Pseudosecond-order kinetic plot for sorption. (b) $\mathrm{ReO}_{4}^{-}$sorption curve vs. concentration in TJNU-302 suspension. Inset: Fitting the equilibrium sorption data with Langmuir model. 
To further explore the adsorption thermodynamic properties for $\mathrm{ReO}_{4}^{-}, 5 \mathrm{mg}$ TJNU-302 were immersed in a $10 \mathrm{~mL}$ water solution with different concentrations of $\mathrm{KReO}_{4}(20-500$ ppm). Langmuir and Freundlich sorption models were applied. As a result, the adsorption isotherm of TJNU-302 can be fitted with Langmuir model (Figure 3b). ${ }^{39}$ The correlation coefficient is high $(>0.99)$ and the calculated maximum adsorption capacity for $\mathrm{ReO}_{4}^{-}$is $211 \mathrm{mg}$ per gram of TJNU-302. In addition, the exact amount of Re(VII) adsorption (256 mg per gram) was calculated using the crystal structure data, which is slightly higher but can be experimentally achieved by using a saturated $\mathrm{ReO}_{4}{ }^{-}$water solution. Moreover, the distribution coefficient $\left(K_{\mathrm{d}}\right)$ is usually used to evaluate the performance of anion scavenger, and a $K_{\mathrm{d}}$ value above $1.0 \times 10^{5} \mathrm{~mL} \mathrm{~g}^{-1}$ is considered to be excellent. ${ }^{40}$ The $K_{\mathrm{d}}$ value can be calculated by using the equation $K_{\mathrm{d}}=\left[\left(C_{0}-C_{\mathrm{e}}\right) V / C_{\mathrm{e}}\right] / m$, in which $C_{0}$ and $C_{\mathrm{e}}$ are the initial and equilibrium concentrations of $\mathrm{ReO}_{4}^{-}\left(\mathrm{mL} \mathrm{g}^{-1}\right), V$ is the volume of the treated solution (mL), $m$ is the mass of TJNU-302 (g). Herein, the $K_{\mathrm{d}}$ value of TJNU-302 for $\mathrm{ReO}_{4}^{-}$was calculated to be $5.8 \times 10^{5} \mathrm{~mL} \mathrm{~g}^{-1}$, which is one of the highest for $\mathrm{TcO}_{4}^{-} / \mathrm{ReO}_{4}{ }^{-}$adsorption materials reported so far (Table S4, Supporting Information). ${ }^{41}$

Hydrolytic Stability, Recyclability and Anion Selectivity. The hydrolytic stability under different $\mathrm{pH}$ conditions and recyclability are both critical to anion-exchange materials in practical applications. As demonstrated by PXRD patterns (Figure 4a), TJNU-302 is stable over a wide $\mathrm{pH}$ range from 3 to 13 . However, TJNU-302 will be dissolved in an aqueous solution of $\mathrm{pH}=2$ and be decomposed (Figure $\mathrm{S} 2$, Supporting Information) in an aqueous solution of $\mathrm{pH}=14$. Significantly, the $\mathrm{ReO}_{4}{ }^{-}$removal percentages in the $\mathrm{pH}$ range of 6-9 are nearly $100 \%$ (Figure $4 \mathrm{~b}$ ). Moreover, a slight mass loss of only $6.2 \%$ and $5.6 \%$ is found 
for TJNU-302 solid before and after the treatment by water solutions with $\mathrm{pH}=3$ and 13 , respectively, further indicating its hydrolytic stability. ${ }^{42}$ Additionally, the $\mathrm{ReO}_{4}{ }^{-}$-loaded TJNU-302 can be regenerated by washing with $\mathrm{NaSbF}_{6}$ solution at least for six cycles, as revealed by PXRD patterns (Figure S3, Supporting Information). The regenerated TJNU302 can also remove ca. $82 \% \mathrm{ReO}_{4}^{-}$from the water solution (Figure $4 \mathrm{c}$ ). This is significant for such a porous sorbent, since the cost of TJNU-302 is ca. 500 US dollars per kilogram. Most $\mathrm{TcO}_{4}{ }^{-} / \mathrm{ReO}_{4}{ }^{-}$sorbents, especially inorganic cationic materials and anion-exchange resins, normally exhibit low selectivity in the presence of competing anions (e.g. carbonate and phosphate). ${ }^{6-9}$ To this end, the competing selectivity for $\mathrm{CO}_{3}{ }^{2-} / \mathrm{ReO}_{4}{ }^{-}$and $\mathrm{PO}_{4}{ }^{3-} / \mathrm{ReO}_{4}{ }^{-}$ was explored. As shown in Figure 4d, the removal percentages of $\mathrm{ReO}_{4}{ }^{-}$remain as high as $83.2 \%$ and $81.7 \%$ for TJNU-302, even the concentration of $\mathrm{CO}_{3}{ }^{2-}$ and $\mathrm{PO}_{4}{ }^{3-}$ is 500 times in excess. Further, the removal percentages of $\mathrm{ReO}_{4}^{-}$by TJNU-302 are all as high as over $80 \%$, in the presence of 1000 times of $\mathrm{SO}_{4}{ }^{2-}, 50$ times of $\mathrm{NO}_{3}^{-}, 20$ times of $\mathrm{CF}_{3} \mathrm{COO}^{-}, 20$ times of $\mathrm{CH}_{3} \mathrm{SO}_{3}{ }^{-}$, and 10 times of $\mathrm{F}^{-}$in excess (Figure $\mathrm{S} 4$, Supporting Information). 

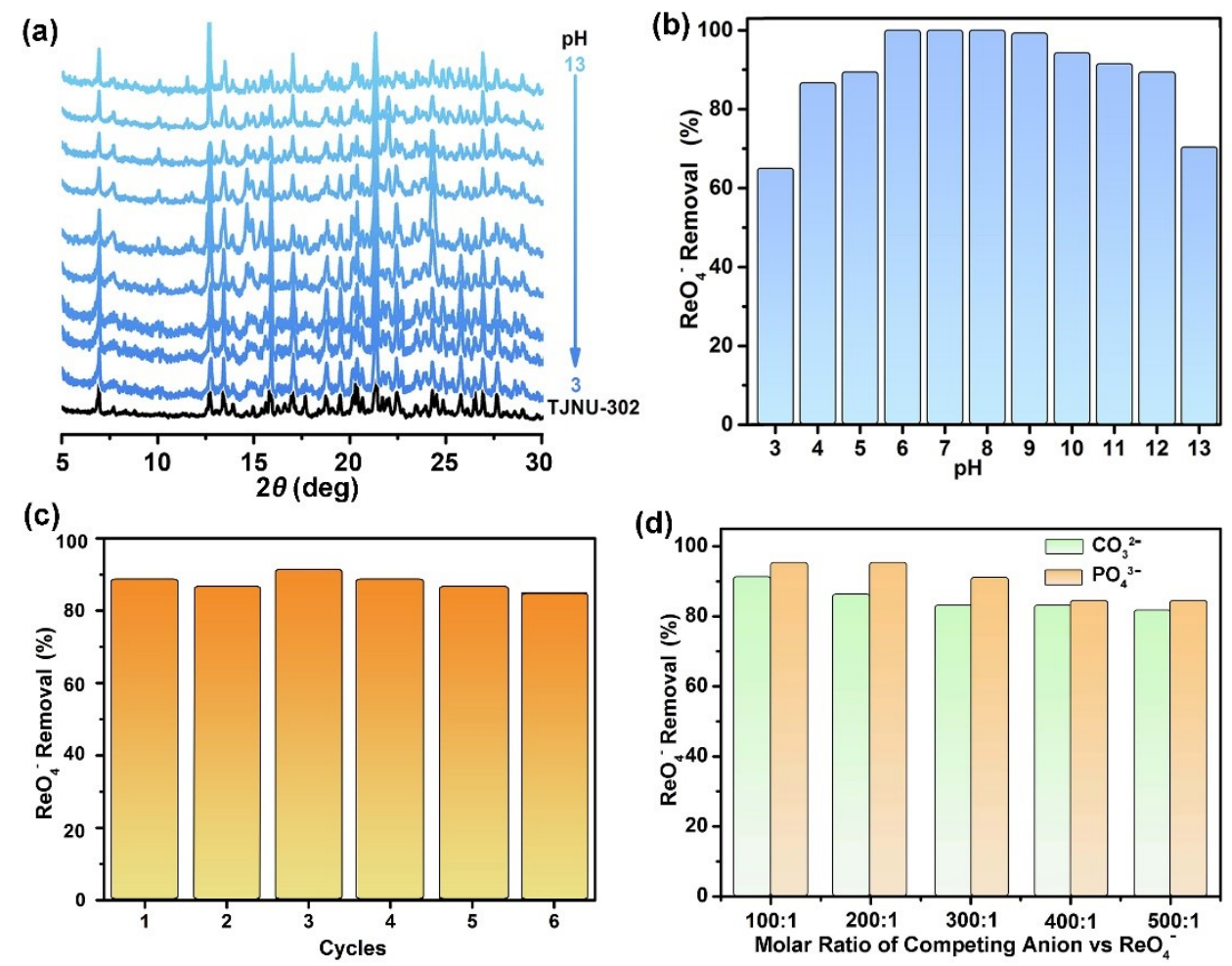

Figure 4. (a) PXRD patterns of TJNU-302 after soaking in water solutions with $\mathrm{pH}=3$ -

13. (b) Removal percentages of $\mathrm{ReO}_{4}^{-}$by TJNU-302 under $\mathrm{pH}=3-13$. (c) Removal percentages of $\mathrm{ReO}_{4}{ }^{-}$by TJNU-302 after different cycles. (d) Removal percentages of $\mathrm{ReO}_{4}{ }^{-}$by TJNU-302 in $\mathrm{ReO}_{4}{ }^{-} / \mathrm{CO}_{3}{ }^{2-}$ or $\mathrm{ReO}_{4}{ }^{-} / \mathrm{PO}_{4}{ }^{3-}$ mixtures with various ratios.

Structure-Property Correlation. The underlying reason for outstanding $\mathrm{ReO}_{4}{ }^{-}$removal selectivity by TJNU-302 can be elucidated based on a molecular-scale analysis. Recently, SC-SC transformation has been considered as the most convincing approach to study anion exchange process, with the aid of single crystal X-ray diffraction technique. ${ }^{43}$ Herein, the $\mathrm{ReO}_{4}{ }^{-}$-loaded crystal TJNU-302(Re), namely $[\mathrm{Ag}(1,2,4,5-\mathrm{p} 4 \mathrm{~b})]\left(\mathrm{ReO}_{4}\right)$, was successfully obtained. TJNU-302(Re) is monoclinic with $a=14.3428(3), b=8.6193(2), c=20.2530(5)$ $\AA, \beta=101.798(2)^{\circ}$, and space group $P 2_{1} / n$. It can be viewed as an isostructure of TJNU302 , with changes of the unit cell parameters of $+1.2 \% a,-2.0 \% b,-1.3 \% c,-0.51^{\circ} \beta$ and - 
$2.0 \% V$ (Table $\mathrm{S} 1$, Supporting Information). Structural analysis shows that each $\mathrm{ReO}_{4}^{-}$ion can be firmly trapped by four hydrogen bonds with pyridyl groups of $1,2,4,5-\mathrm{p} 4 \mathrm{~b}$, with the $\mathrm{H} \cdots \mathrm{O}$ distances in 2.55-2.59 $\AA$ range (Figure 5 and Table S5, Supporting Information). Moreover, $\mathrm{SiF}_{6}{ }^{2-}$ anion has a radius of $2.59 \AA$, which is very similar to that of $\mathrm{ReO}_{4}^{-}(2.60$ A). ${ }^{44}$ These structural features are beneficial to provide matching space for $\mathrm{ReO}_{4}{ }^{-}$trapping. As stated above, TJNU-302 has a high sorption selectivity to $\mathrm{ReO}_{4}^{-}$, which is attributed to a combination of favorable charge and size of $\mathrm{ReO}_{4}^{-}$ion for the host-guest interaction. $\mathrm{ReO}_{4}^{-}$is a monovalent anion with large size, overall showing a lower charge density. Thus, compared to $\mathrm{SO}_{4}{ }^{2-}, \mathrm{CO}_{3}{ }^{2-}, \mathrm{NO}_{3}{ }^{-}, \mathrm{PO}_{4}{ }^{3-}, \mathrm{CF}_{3} \mathrm{COO}^{-}, \mathrm{CH}_{3} \mathrm{SO}_{3}{ }^{-}$, and $\mathrm{F}^{-}, \mathrm{ReO}_{4}{ }^{-}$anion is more hydrophobic and readily to transport from the water solution to anion-exchange materials. According to the experiments and Mulliken population analysis, both $\mathrm{TcO}_{4}{ }^{-} / \mathrm{ReO}_{4}{ }^{-}$anions have low hydration energy and only modest charge density on oxygen atoms. ${ }^{44}$ In detail, the hydration energy $\left(\Delta G_{\mathrm{h}}{ }^{\circ}\right)$ is significantly different between $\mathrm{ReO}_{4}^{-}\left(-330 \mathrm{~kJ} \mathrm{~mol}^{-1}\right)$ and $\mathrm{CO}_{3}{ }^{2-}\left(-1315 \mathrm{~kJ} \mathrm{~mol}^{-1}\right) / \mathrm{PO}_{4}{ }^{3-}\left(-2773 \mathrm{~kJ} \mathrm{~mol}^{-1}\right){ }^{5,45}$ That is, it is unnecessary for $\mathrm{ReO}_{4}{ }^{-}$to overcome a high energy barrier during dehydration. Due to the hydrophobicity of the pores for TJNU-302, it prefers trapping $\mathrm{ReO}_{4}{ }^{-}$than $\mathrm{CO}_{3}{ }^{2-}$ and $\mathrm{PO}_{4}{ }^{3-}$. In addition, the presence of multiple hydrogen-bonding interactions will also boost its anion-exchange selectivity. 


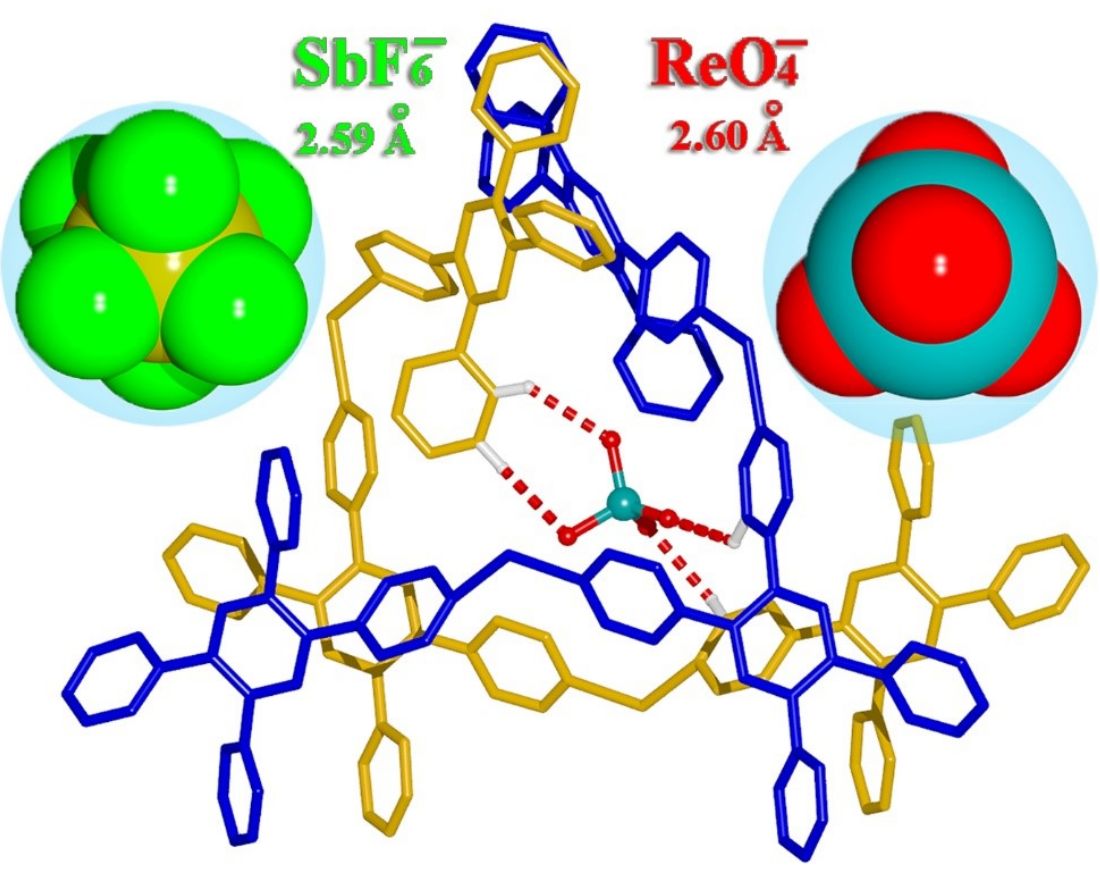

Figure 5. Schematic drawing of the anion radii for $\mathrm{SbF}_{6}{ }^{-}$and $\mathrm{ReO}_{4}^{-}$, and multiple hydrogen bonds between $\mathrm{ReO}_{4}{ }^{-}$and the coordination network in TJNU-302(Re).

To further illustrate the intrinsic driving force for $\mathrm{ReO}_{4}^{-}$trapping by TJNU-302, the DFT calculations were performed for TJNU-302 and TJNU-302(Re). Molecular orbital analyses indicate that there is scarcely any interaction between the $p$ orbitals of $\mathrm{F}$ in $\mathrm{SbF}_{6}{ }^{-}$and the $\pi$ orbitals of imidazole ring in TJNU-302 (Figure S5, Supporting Information). However, in TJNU-302(Re), the $\pi$ bonds hybridize with the $p$ lone pair electrons of $\mathrm{ReO}_{4}^{-}$anions, which indicate the relatively strong interactions.

Luminescence Sensing. The luminescent properties of TJNU-302 in water solution were initially investigated with a handheld UV lamp. Upon $254 \mathrm{~nm}$ irradiation, a noticeable and typical fluorescence of the TJNU-302 crystals appears (Figure 6a left). While in the $\mathrm{ReO}_{4}{ }^{-}$ solution, a fluorescent quenching effect is observed for the crystals (Figure 6a right). This is a solid-state luminescence sensor for $\mathrm{ReO}_{4}{ }^{-}$anion, which is clearly more convenient than 
the reported suspension sensors. To further evaluate its practicability, a test paper for $\mathrm{ReO}_{4}{ }^{-}$ was fabricated. In detail, a piece of filter paper was dipped into a water solution $(3 \mathrm{~mL})$ of TJNU-302 (1 mg), and then allowed to air-dry. By using an ink of $\mathrm{ReO}_{4}^{-}\left(0.02 \mathrm{~mol} \mathrm{~L}^{-1}\right)$, a written word of "Re" clearly appears on the test paper under $254 \mathrm{~nm}$ irradiation (Figure $6 \mathrm{~b}$ inset).
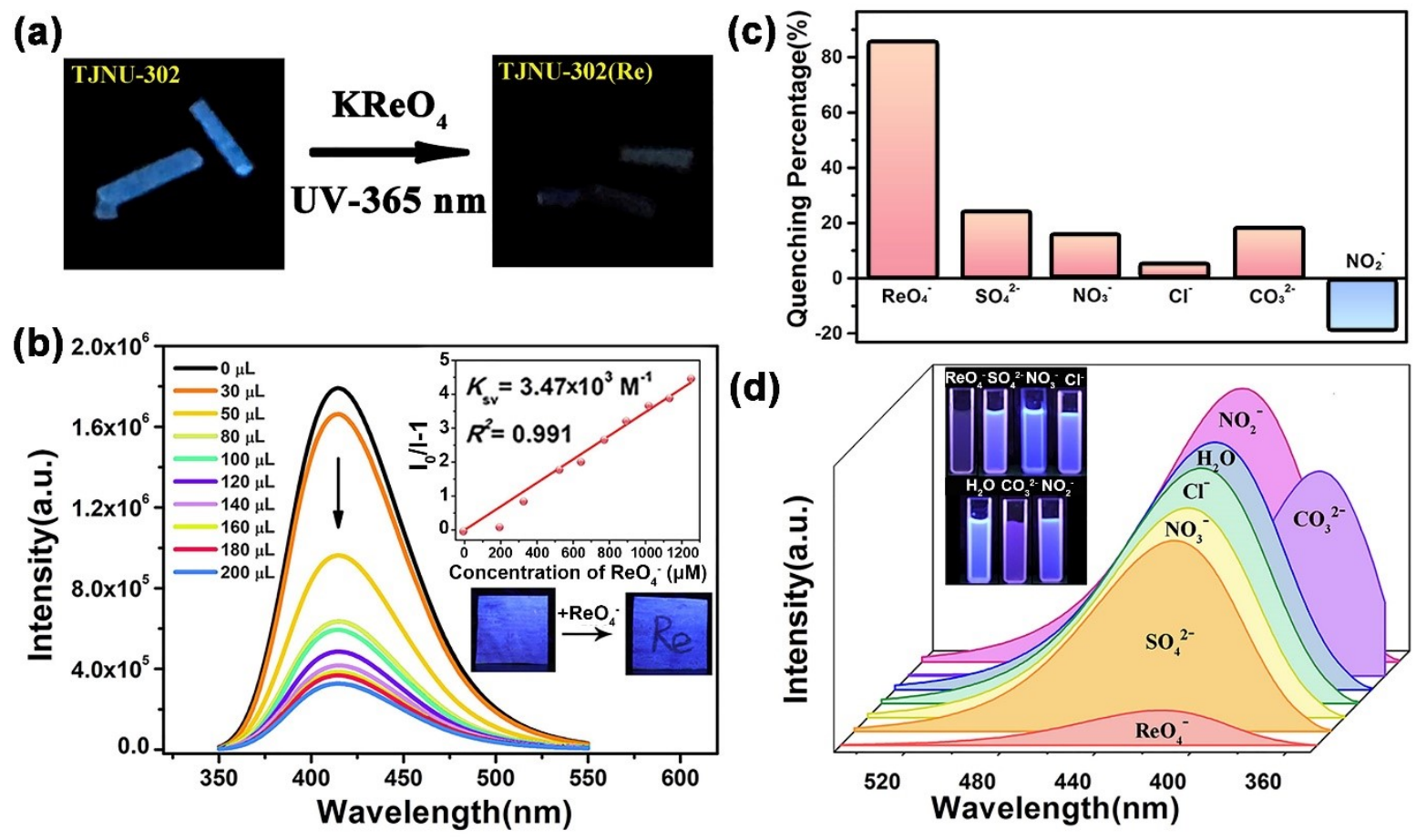

Figure 6. (a) UV photos of TJNU-302 crystals before and after immersing in $\mathrm{KReO}_{4}$ water solution. (b) The emission spectra and $K_{\mathrm{sv}}$ value of TJNU-302 titrated with $\mathrm{KReO}_{4}$ water solution. Inset: the photos of test paper experiment for $\mathrm{ReO}_{4}^{-}$. (c) Luminescence quenching percentages and (d) emission spectra of TJNU-302 in water solutions containing different anions. Inset: corresponding luminescence photos of TJNU-302.

To further determine the sensing performance of TJNU-302, the fluorescence quenching experiments were performed through stepwise adding the water solution $\left(0.02 \mathrm{~mol} \mathrm{~L}^{-1}\right)$ of 
$\mathrm{KReO}_{4}$. As shown in Figure 6b, the aqueous suspension of TJNU-302 exhibits an obvious emission at $416 \mathrm{~nm}$ upon exciting at $324 \mathrm{~nm}$. In comparison, a similar emission is found at $373 \mathrm{~nm}$ (Figure S6, Supporting Information) for the 1,2,4,5-p4b ligand, upon exciting at $300 \mathrm{~nm}$. Therefore, the origin of fluorescence emission for TJNU-302 could preliminarily be attributed to ligand-centered $\pi-\pi^{*}$ transitions and/or the incorporation of metal-ligand interactions. ${ }^{46}$ By adding $\mathrm{KReO}_{4}$ water solution, the emission intensity decreases with the quenching percentage (QP) of 86\% at most for TJNU-302 suspension. Based on the SternVolmer equation, a good linear relationship with the correlation coefficient $\left(R^{2}\right)$ of 0.991 and quenching constant $\left(K_{\mathrm{sv}}\right)$ of $3.47 \times 10^{3} \mathrm{~L} \mathrm{~mol}^{-1}$ can be obtained. The limit of detection (LOD) is $90 \mu \mathrm{M}$, as calculated according to $3 \sigma /$ slope. Here, $\sigma$ is determined by the equation $\sigma=100 \times\left(I_{\mathrm{SE}} / I_{0}\right)$, in which $I_{\mathrm{SE}}$ is the standard error of the blank measurement and $I_{0}$ is the measured luminescence intensity of TJNU-302 in water. Although several materials show the turn-on or turn-off luminescent sensing to $\mathrm{ReO}_{4}^{-} / \mathrm{TcO}_{4}^{-}$ions, TJNU-302 significantly has the highest quenching efficiency (Table S6, Supporting Information). To illustrate the effect of $\mathrm{pH}$ on the sensing performances, $\mathrm{KReO}_{4}$ water solution was added to the aqueous suspensions of TJNU-302 of different pH values. Similar quenching were also observed (Figure S7, Supporting Information) to reveal the $\mathrm{pH}$-independent sensing performance.

The outstanding sensing ability of TJNU-302 toward $\mathrm{ReO}_{4}^{-}$promotes us to further study its response to other anions in the simulated Hanford LAW Melter recycle stream. A finely ground powder of TJNU-302 (1 mg) was dispersed into $3 \mathrm{~mL}$ water solution, to which 100 $\mu \mathrm{L}$ of $0.2 \mathrm{~mol} \mathrm{~L}{ }^{-1}$ anion solution $\left(\mathrm{SO}_{4}{ }^{2-}, \mathrm{NO}_{3}{ }^{-}, \mathrm{Cl}^{-}, \mathrm{CO}_{3}{ }^{2-}\right.$ or $\left.\mathrm{NO}_{2}{ }^{-}\right)$or $100 \mu \mathrm{L}$ of $0.02 \mathrm{~mol}$ $\mathrm{L}^{-1} \mathrm{ReO}_{4}^{-}$solution was added. As shown in Figures $6 \mathrm{c}$ and $6 \mathrm{~d}$, although the molar ratio of 
anion: $\mathrm{ReO}_{4}^{-}$is 10: 1 , TJNU-302 exhibits the highest quenching percentage toward $\mathrm{ReO}_{4}^{-}$. For $\mathrm{Cl}^{-}, \mathrm{NO}_{3}{ }^{-}, \mathrm{CO}_{3}{ }^{2-}$, and $\mathrm{SO}_{4}{ }^{2-}$ anions, it shows the quenching percentages of $4.6-27.7 \%$. However, the addition of $\mathrm{CO}_{3}{ }^{2-}$ to TJNU-302 suspension leads to the shift of fluorescence emission to $377 \mathrm{~nm}$. A possible explanation is that the $\mathrm{CO}_{3}{ }^{2-}$ anion could strongly interact with $\operatorname{Ag}(\mathrm{I})$ center to break the charge transfer between metal and ligand. ${ }^{47,48}$ Therefore, the fluorescence emission is likely to derive from ligand-centered $\pi-\pi^{*}$ transitions (Figure S6, Supporting Information). ${ }^{49} \mathrm{As}$ for $\mathrm{NO}_{2}^{-}$ion, the luminescence intensity slightly increases by $10.5 \%$. We may conclude that, the incorporated nitrite acts as electron donating moiety to generate hydrogen-bonding interaction with the ligand, promoting the electron transfer between metal and ligand. ${ }^{30,50}$ Moreover, by adding the simulated Hanford LAW Melter Recycle stream $(100 \mu \mathrm{L})$ to TJNU-302 (1 mg) suspension, the luminescence intensity will increase by $14.6 \%$ (Figure S8, Supporting Information). This is due to the high molar ratio of $\mathrm{NO}_{2}^{-}: \mathrm{ReO}_{4}^{-}$(873: 1). In contrast, when the simulated stream of LAW without $\mathrm{ReO}_{4}^{-}$ was added to the suspension of TJNU-302, the fluorescence intensity largely increased by $46.9 \%$, revealing the quenching effect of $\mathrm{ReO}_{4}^{-}$.

It is critical to study the luminescence mechanism of TJNU-302 in order to elucidate its luminescent quenching to $\mathrm{ReO}_{4}{ }^{-} / \mathrm{TcO}_{4}^{-}$. As stated above, the $\pi$-conjugated aromatic ligand in TJNU-302 plays an essential role in its fluorescence properties (Figure S6, Supporting Information). ${ }^{51}$ Generally, two possible mechanisms may be hypothesized for such sensing systems. First, the UV-vis absorption peaks of TJNU-302 and $\mathrm{ReO}_{4}{ }^{-}$show a partial overlap (Figure S9, Supporting Information). Thus, the competition of $\mathrm{ReO}_{4}^{-}$and host framework in absorbing the excitation light may lead to the luminescent quenching. ${ }^{52-54}$ Moreover, the 
intramolecular deactivation must be taken into account. Since TJNU-302 is stable in water solution of $\mathrm{ReO}_{4}^{-}$, the quenching is not a result of degradation of the crystalline phase and instead, of the interaction between the chromophore (ligand) and $\mathrm{ReO}_{4}{ }^{-}$. As confirmed by SC-XRD, $\mathrm{ReO}_{4}{ }^{-}$could establish strong H-bonding interactions with the host framework. As a result, H-bonding interactions between the anion and host framework may destabilize the orbital energy level of $s p^{2} \mathrm{C}$, which promote the intramolecular electron transformation. Thus, it can be concluded that the ligand-to- $\mathrm{ReO}_{4}{ }^{-}$electron transfer will also be responsible for the observed fluorescence quenching. ${ }^{30,32,55}$

\section{CONCLUSION}

In this work, a cationic $\mathrm{CP}$ sensor has been designed and synthesized for detection of $\mathrm{ReO}_{4}^{-}$ anion, which shows the highest efficiency among all reported $\mathrm{ReO}_{4}^{-}$sensors. This porous material also exhibits high $\mathrm{ReO}_{4}^{-}$-exchange capacity and selectivity, which can be properly explained by the molecular-scale crystal structure analysis of the anion-exchange product via SC-SC transformation, and further verified by DFT calculations. Remarkably, relying on the solid-state UV-quenching effect of TJNU-302 on perrhenate, a $\mathrm{ReO}_{4}^{-}$test paper can be produced. The results will not only present a new $\mathrm{CP}$ material with potential application in design of instant sensors, but also provide useful insights into understanding the anionexchange process or mechanism for such porous crystalline materials.

\section{ASSOCIATED CONTENT}

Supporting Information. The Supporting Information is available free of charge on the ACS Publications website at DOI: 10.1021/acsami.xxxxxxx. 
Tables for Crystallographic parameters, selective bond lengths and angles, composition of simulated Hanford LAW melter off-gas scrubber solution, adsorption efficiency of $\mathrm{ReO}_{4}^{-}$, hydrogen-bonding geometries, comparison of the reported luminescent sensors; Figures for topological network of TJNU-302, PXRD patterns under different conditions, FT-IR and removal percentages of $\mathrm{ReO}_{4}^{-}$and competing anions, molecular orbital interaction, and luminescent and UV-vis spectra.

\section{AUTHOR INFORMATION}

\section{Corresponding Author}

E-mail: hxxydm@tjnu.edu.cn (M. Du),wzhou@st-andrews.ac.uk (W.Zhou)

\section{Notes}

The authors declare no competing financial interest.

\section{ACKNOWLEDGMENTS}

This work was financially supported by the National Natural Science Foundation of China (21771139), Tianjin Natural Science Foundation (17JCYBJC22800), and the Program for Innovative Research Team in University of Tianjin (TD13-5074).

\section{REFERENCES}

[1] Oliver, S. R. J. Cationic Inorganic Materials for Anionic Pollutant Trapping and Catalysis. Chem. Soc. Rev. 2009, 38, 1868-1881.

[2] Smith, F. N.; Taylor, C. D.; Um, W.; Kruger, A. A. Technetium Incorporation into Goethite $(\alpha-$ FeOOH): An Atomic-Scale Investigation. Environ. Sci. Technol. 2015, 49, 13699-13707.

[3] Lumetta, G. J.; Moyer, B. A.; Singh, R. P. Fundamentals and Applications of Anion Separations; Kluwer Academic / Plenum: New York, USA, 2004. 
[4] Attix, F. H. Introduction to Radiological Physics and Radiation Dosimetry; Wiley-VCH: Weinheim, Germany, 1986.

[5] Banerjee, D.; Kim, D.; Schweiger, M. J.; Kruger, A. A.; Thallapally, P. K. Removal of TcO $4^{-} \mathrm{Ions}^{-}$ from Solution: Materials and Future Outlook. Chem. Soc. Rev. 2016, 45, 2724-2739.

[6] Li, J.; Zhu, L.; Xiao, C.; Chen, L.; Chai, Z.; Wang, S. Efficient Uptake of Perrhenate/Pertechnetate from Aqueous Solutions by the Bifunctional Anion-Exchange Resin. Radiochim. Acta 2018, 106, 581-591.

[7] Bonnesen, P. V.; Brown, G. M.; Alexandratos, S. D.; Bavoux, L. B.; Presley, D. J.; Patel, V.; Ober, R.; Moyer, B. A. Development of Bifunctional Anion-Exchange Resins with Improved Selectivity and Sorptive Kinetics for Pertechnetate: Batch-Equilibrium Experiments. Environ. Sci. Technol. 2000, 34, 3761-3766.

[8] Katayev, E. A.; Kolesnikov, G. V.; Sessler, J. L. Molecular Recognition of Pertechnetate and Perrhenate. Chem. Soc. Rev. 2009, 38, 1572-1586.

[9] Lim, J. Y. C.; Beer, P. D. Superior Perrhenate Anion Recognition in Water by a Halogen Bonding Acyclic Receptor. Chem. Commun. 2015, 51, 3686-3688.

[10] Wang, S.; Yu, P.; Purse, B. A.; Orta, M. J.; Diwu, J.; Casey, W. H.; Phillips, B. L.; Alekseev, E. V.; Depmeier, W.; Hobbs, D. T.; Albrecht-Schmitt, T. E. Selectivity, Kinetics, and Efficiency of Reversible Anion Exchange with $\mathrm{TcO}_{4}{ }^{-}$in a Supertetrahedral Cationic Framework. Adv. Funct. Mater. 2012, 22, 2241-2250.

[11] Sun, Q.; Zhu, L.; Aguila, B.; Thallapally, P. K.; Xu, C.; Chen, J.; Wang, S.; Rogers, D.; Ma, S. Optimizing Radionuclide Sequestration in Anion Nanotraps with Record Pertechnetate Sorption. Nat. Commun. 2019, 10, 1646.

[12] Banerjee, D.; Elsaidi, S. K.; Aguila, B.; Li, B.; Kim, D.; Schweiger, M. J.; Kruger, A. A.; Doonan, C. J.; Ma, S.; Thallapally, P. K. Removal of Pertechnetate-Related Oxyanions from Solution Using Functionalized Hierarchical Porous Frameworks. Chem. Eur. J. 2016, 22, 17581-17584. 
[13] Zhang, W.; Aguila, B.; Ma, S. Potential Applications of Functional Porous Organic Polymer Materials, J. Mater. Chem. A 2017, 5, 8795-8824.

[14] Li, J.; Dai, X.; Zhu, L.; Xu, C.; Zhang, D.; Silver, M. A.; Li, P.; Chen, L.; Li, Y.; Zuo, D.; Zhang, H.; Xiao, C.; Chen, J.; Diwu, J.; Farha, O. K.; Albrecht-Schmitt, T. E.; Chai, Z.; Wang, S. ${ }^{99}$ TcO $_{4}{ }^{-}$ Remediation by a Cationic Polymeric Network. Nat. Commun. 2018, 9, 3007.

[15] He, L.; Liu, S.; Chen, L.; Dai, X.; Li, J.; Zhang, M.; Ma, F.; Zhang, C.; Yang, Z.; Zhou, R.; Chai, Z.; Wang, S. Mechanism Unravelling for Ultrafast and Selective ${ }^{99} \mathrm{TcO}_{4}{ }^{-}$Uptake by a RadiationResistant Cationic Covalent Organic Framework: A Combined Radiological Experiment and Molecular Dynamics Simulation Study. Chem. Sci. 2019, 10, 4293-4305.

[16] Liu, Z.-W.; Han, B.-H. Evaluation of an Imidazolium-Based Porous Organic Polymer as Radioactive Waste Scavenger. Environ. Sci. Technol. 2020, 54, 216-224.

[17] Fei, H. H.; Bresler, M. R.; Oliver, S. R. J. A New Paradigm for Anion Trapping in High Capacity and Selectivity: Crystal-to-Crystal Transformation of Cationic Materials. J. Am. Chem. Soc. 2011, $133,11110-11113$.

[18] Li, C. P.; Ai, J. Y.; Zhou, H.; Chen, Q.; Yang, Y. J.; He, H. M.; Du, M. Ultra-Highly Selective Trapping of Perrhenate/Pertechnetate by a Flexible Cationic Coordination Framework. Chem. Commun. 2019, 55, 1841-1844.

[19] Sheng, D.; Zhu, L.; Dai, X.; Xu, C.; Li, P.; Pearce, C. I.; Xiao, C.; Chen, J.; Zhou, R.; Duan, T.; Farha, O. K.; Chai, Z.; Wang, S. Successful Decontamination of ${ }^{99} \mathrm{TcO}_{4}^{-}$in Groundwater at Legacy Nuclear Sites by a Cationic Metal-Organic Framework with Hydrophobic Pockets. Angew. Chem., Int. Ed. 2019, 58, 4968-4972.

[20] Li, C. P.; Zhou, H.; Wang, J. J.; Liu, B. L.; Wang, S.; Yang, X.; Wang, Z. L.; Liu, C. S.; Du, M.; Zhou, W. Z. Mechanism-Property Correlation in Coordination Polymer Crystals toward Design of a Superior Sorbent. ACS Appl. Mater. Interfaces 2019, 11, 42375-42384.

[21] Karmakar, A.; Desai, A. V.; Ghosh, S. K. Ionic Metal-Organic Frameworks (IMOFs): Design Principles and Applications. Coord. Chem. Rev. 2016, 307, 313-341. 
[22] Zhao, J.; Wang, Y. N.; Dong, W. W.; Wu, Y. P.; Li, D. S.; Liu, B.; Zhang, Q. A New SurfactantIntroduction Strategy for Separating the Pure Single-Phase of Metal-Organic Frameworks. Chem. Commun. 2015, 51, 9479-9482.

[23] Li, C. P.; Zhou, H.; Wang, S.; Chen, J.; Wang, Z. L.; Du, M. Highly Efficient $\mathrm{Cr}_{2} \mathrm{O}_{7}{ }^{2-}$ Removal of a 3D Metal-Organic Framework Fabricated by Tandem Single-Crystal to Single-Crystal Transformations from a 1D Coordination Array. Chem. Commun. 2017, 53, 9206-9209.

[24] Fu, H. R.; Wang, N.; Qin, J. H.; Han, M. L.; Ma, L. F.; Wang, F. Spatial Confinement of a Cationic MOF: A SC-SC Approach for High Capacity Cr(VI)-Oxyanion Capture in Aqueous Solution. Chem. Commun. 2018, 54, 11645-11648.

[25] Zhu, L.; Sheng, D.; Xu, C.; Dai, X.; Silver, M. A.; Li, J.; Li, P.; Wang, Y.; Wang, Y.; Chen, L.; Xiao, C.; Chen, J.; Zhou, R.; Zhang, C.; Farha, O. K.; Chai, Z.; Albrecht-Schmitt, T. E.; Wang, S. Identifying the Recognition Site for Selective Trapping of ${ }^{99} \mathrm{TcO}_{4}{ }^{-}$in a Hydrolytically Stable and Radiation Resistant Cationic Metal-Organic Framework. J. Am. Chem. Soc. 2017, 139, $14873-$ 14876.

[26] Sheng, D.; Zhu, L.; Xu, C.; Xiao, C.; Wang, Y.; Wang, Y.; Chen, L.; Diwu, J.; Chen, J.; Chai, Z.; Albrecht-Schmitt, T. E.; Wang, S. Efficient and Selective Uptake of $\mathrm{TcO}_{4}^{-}$by a Cationic MetalOrganic Framework Material with Open $\mathrm{Ag}^{+}$Sites. Environ. Sci. Technol. 2017, 51, 3471-3479.

[27] Phelps, T. E.; Bhawawet, N.; Jurisson, S. S.; Baker, G. A. Efficient and Selective Extraction of ${ }^{99} \mathrm{TcO}_{4}^{-}$from Aqueous Media Using Hydrophobic Deep Eutectic Solvents. ACS Sustain. Chem. Eng. 2018, 6, 13656-13661.

[28] Chatterjee, S.; Norton, A. E.; Edwards, M. K.; Peterson, J. M.; Taylor, S. D.; Bryan, S. A.; Andersen, A.; Govind, N.; Albrecht-Schmitt, T. E.; Connick, W. B.; Levitskaia, T. G. Highly Selective Colorimetric and Luminescence Response of a Square-Planar Platinum(II) Terpyridyl Complex to Aqueous $\mathrm{TcO}_{4}^{-}$. Inorg. Chem. 2015, 54, 9914-9923. 
[29] Desai, A. M.; Singh, P. K. Ratiometric Fluorescence Turn-On Sensing of Perrhenate Anion, a NonRadioactive Surrogate of Hazardous Pertechnetate, in Aqueous Solution. Sensor Actuat. B-Chem. 2018, 277, 205-209.

[30] Amendola, V.; Bergamaschi, G.; Boiocchi, M.; Alberto, R.; Braband, H. Fluorescent Sensing of ${ }^{99}$ Tc Pertechnetate in Water. Chem. Sci. 2014, 5, 1820-1826.

[31] Desai, A. M.; Singh, P. K. An Ultrafast Molecular-Rotor-Based Fluorescent Turn-On Sensor for the Perrhenate Anion in Aqueous Solution. Chem. Eur. J. 2019, 25, 2035-2042.

[32] Rapti, S.; Diamantis, S. A.; Dafnomili, A.; Pournara, A.; Skliri, E.; Armatas, G. S.; Tsipis, A. C.; Spanopoulos, I.; Malliakas, C. D.; Kanatzidis, M. G.; Plakatouras, J. C.; Noli, F.; Lazarides, T.; Manos, M. J. Exceptional $\mathrm{TcO}_{4}{ }^{-}$Sorption Capacity and Highly Efficient $\mathrm{ReO}_{4}{ }^{-}$Luminescence Sensing by $\mathrm{Zr}^{4+}$ MOFs. J. Mater. Chem. A 2018, 6, 20813-20821.

[33] Blöchl, P. E. Projector Augmented-Wave Method, Phys. Rev. B 1994, 50, 17953-17979.

[34] Kresse, G.; Joubert, D. From Ultrasoft Pseudopotentials to the Projector Augmented-Wave Method. Phys. Rev. B 1999, 59, 1758-1775.

[35] Kresse, G.; Hafner, J. Ab initio Molecular Dynamics for Liquid Metals. Phys. Rev. B 1993, 47, 558561.

[36] Perdew, J. P.; Burke, K.; Ernzerhof, M. Generalized Gradient Approximation Made Simple. Phys. Rev. Lett. 1996, 77, 3865-3868.

[37] Grimme, S. Semiempirical GGA-Type Density Functional Constructed with a Long-Range Dispersion Correction. J. Comput. Chem. 2006, 27, 1787-1799.

[38] Monkhorst, H. J.; Pack, J. D. Special Points for Brillouin-Zone Integrations. Phys. Rev. B 1976, 13, 5188-5192.

[39] Shao, Z.; Huang, C.; Wu, Q.; Zhao, Y.; Xu, W.; Liu, Y.; Dang, J.; Hou, H. Ion Exchange Collaborating Coordination Substitution: More Efficient Cr(VI) Removal Performance of a Waterstable $\mathrm{Cu}^{\mathrm{II}}$-MOF Material. J. Hazard. Mater. 2019, 378, 120719. 
[40] Li, B.; Zhang, Y.; Ma, D.; Shi, Z.; Ma, S. Mercury Nano-Trap for Effective and Efficient Removal of Mercury(II) from Aqueous Solution. Nat. Commun. 2014, 5, 5537.

[41] Li, D.; Seaman, J. C.; Kaplan, D. I.; Heald, S. M.; Sun, C. J. Pertechnetate $\left(\mathrm{TcO}_{4}^{-}\right)$Sequestration from Groundwater by Cost-Effective Organoclays and Granular Activated Carbon under Oxic Environmental Conditions. Chem. Eng. J. 2019, 360, 1-9.

[42] Xu, W.; Shao, Z.; Huang, C.; Xu, R.; Dong, B.; Hou, H. Alkenone-enol-alkenone [2+2+2] Cyclotrimerization Producing Functional Coordination Polymers with Excellent Adsorption Performance. Inorg. Chem. 2019, 58, 3959-3967.

[43] Li, C. P.; Chen, J.; Liu, C. S.; Du, M. Dynamic Structural Transformations of Coordination Supramolecular Systems upon Exogenous Stimulation. Chem. Commun. 2015, 51, 2768-2781.

[44] Schulz, W. W.; Lombardo, N. J. Science and Technology for Disposal of Radioactive Tank Wastes; Plenum Press: New York, USA, 1998.

[45] Xiao, C.; Khayambashi, A.; Wang, S. Separation and Remediation of ${ }^{99} \mathrm{TcO}_{4}^{-}$from Aqueous Solutions. Chem. Mater. 2019, 31, 3863-3877.

[46] Cui, Y.; Yue, Y.; Qian, G.; Chen, B. Luminescent Functional Metal-Organic Frameworks. Chem. Rev. 2012, 112, 1126-1162.

[47] He, L.; Liu, C.; Xin, J. H. A Novel Turn-On Colorimetric and Fluorescent Sensor for $\mathrm{Fe}^{3+}$ and $\mathrm{Al}^{3+}$ with Solvent-Dependent Binding Properties and Its Sequential Response to Carbonate. Sensor Actuat. B-Chem. 2015, 213, 181-187.

[48] Sun, N. N.; Yan, B. Rapid and Facile Ratiometric Detection of $\mathrm{CO}_{3}{ }^{2-}$ Based on Heterobimetallic Metal-Organic Frameworks (Eu/Pt-MOFs). Dye Pigments 2017, 142, 1-7.

[49] Li, C. P.; Ai, J. Y.; He, H. M.; Li, M. Z.; Du, M. Divergent Structural Transformations in 3D Ag(I) Porous Coordination Polymers Induced by Solvent and Anion Exchanges. Cryst. Growth Des. 2019, $19,2235-2244$

[50] Karmakar, A.; Samanta, P.; Dutta, S.; Ghosh, S. K. Fluorescent “Turn-on” Sensing Based on MetalOrganic Frameworks (MOFs). Chem. Asian J. 2019, 20, 4506-4519. 
[51] Chang, Y. C.; Wang, S. L. From Stimuli-Responsive Polymorphic Organic Dye Crystals to Photoluminescent Cationic Open-Framework Metal Phosphate. J. Am. Chem. Soc. 2012, 134, 98489851.

[52] Fu, H. R.; Wu, X. X.; Ma, L. F.; Wang, F.; Zhang, J. Dual-Emission SG7@MOF Sensor via SCSC Transformation: Enhancing the Formation of Excimer Emission and the Range and Sensitivity of Detection. ACS Appl. Mater. Interfaces 2018, 10, 18012-18020.

[53] Chen, S.; Shi, Z.; Qin, L.; Jia, H.; Zheng, H. Two New Luminescent Cd(II)-Metal-Organic Frameworks as Bifunctional Chemosensors for Detection of Cations $\mathrm{Fe}^{3+}$, Anions $\mathrm{CrO}_{4}{ }^{2-}$, and $\mathrm{Cr}_{2} \mathrm{O}_{7}{ }^{2-}$ in Aqueous Solution. Cryst. Growth Des. 2017, 17, 67-72.

[54] Liu, W.; Wang, Y.; Bai, Z.; Li, Y.; Wang, Y.; Chen, L.; Xu, L.; Diwu, J.; Chai, Z.; Wang, S. Hydrolytically Stable Luminescent Cationic Metal Organic Framework for Highly Sensitive and Selective Sensing of Chromate Anions in Natural Water Systems. ACS Appl. Mater. Interfaces 2017, 9, 16448-16457.

[55] Chatterjee, S.; Bryan, S. A.; Seliskar, C. J.; Heineman, W. R. Three-Component Spectroelectrochemical Sensor Module for the Detection of Pertechnetate $\left(\mathrm{TcO}_{4}{ }^{-}\right)$. Rev. Anal. Chem. 2013, 32, 209-224. 
Table of Contents

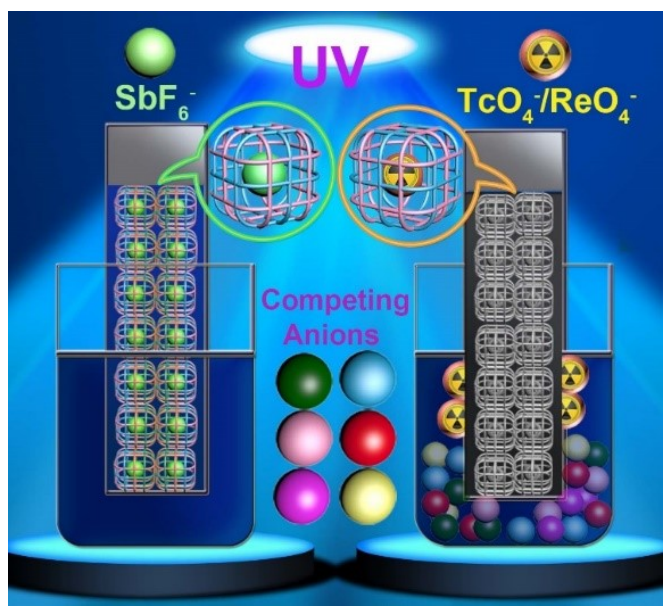

